\title{
Emerging therapies for severe asthma
}

\author{
Neil C Thomson*, Rekha Chaudhuri and Mark Spears
}

\begin{abstract}
Many patients with asthma have poorly controlled symptoms, and particularly for those with severe disease, there is a clear need for improved treatments. Two recent therapies licensed for use in asthma are omalizumab, a humanized monoclonal antibody that binds circulating IgE antibody, and bronchial thermoplasty, which involves the delivery of radio frequency energy to the airways to reduce airway smooth muscle mass. In addition, there are new therapies under development for asthma that have good potential to reach the clinic in the next five years. These include biological agents targeting proinflammatory cytokines such as interleukin-5 and interleukin-13, inhaled ultra long-acting $\beta_{2}$-agonists and once daily inhaled corticosteroids. In addition, drugs that block components of the arachidonic acid pathway that targets neutrophilic asthma and CRTH2 receptor antagonists that inhibit the proinflammatory actions of prostaglandin $\mathrm{D}_{2}$ may become available. We review the recent progress made in developing viable therapies for severe asthma and briefly discuss the idea that development of novel therapies for asthma is likely to increasingly involve the assessment of genotypic and/or phenotypic factors.
\end{abstract}

\section{Introduction}

Asthma is a chronic inflammatory disease of the airways that affects over 300 million individuals worldwide [1]. The majority of adults with asthma have mild or moderate disease that can be controlled by inhaled corticosteroids either alone or in combination with inhaled longacting $\beta_{2}$ agonist bronchodilators [1-3]. Questionnaire surveys however indicate that a considerable proportion of these patients [4], as well as most with severe asthma [5], or who are cigarette smokers [6,7] have poorly controlled asthma. Systematic evaluation can help identify patients with severe asthma from those with difficult-to-

\footnotetext{
* Correspondence: neil.thomson@glasgow.ac.uk

Respiratory Medicine, Institute of Infection, Immunity, \& Inflammation, University of Glasgow, Glasgow, G12 OYN UK
}

treat asthma due to poor adherence, untreated co-morbidities, dysfunctional breathing or psychological problems $[8,9]$. For patients with severe asthma, which accounts for $5 \%$ to $10 \%$ of cases [10], there is a need for improved therapies [10-12]. This mini-review focuses on biological agents, new inhaled long-acting bronchodilators and corticosteroids, arachidonic acid pathway blockers, bronchial thermoplasty plus a range of other anti-inflammatory agents that have been recently licensed or are at an advanced stage of development for patients with severe asthma (Figure 1). In addition, we briefly discuss the idea that the development of novel therapies for asthma is likely increasingly to involve the assessment of genotypic and/or phenotypic factors.

\section{Biological agents}

The first and as yet only biological agent licensed for the treatment of asthma is omalizumab, a humanized monoclonal antibody that binds circulating IgE antibody, preventing it from binding to its specific high-affinity receptor on mast cells and basophils [13]. In patients with allergic asthma, omalizumab treatment improves symptoms and reduces exacerbations $[14,15]$. Clinical trials are also underway to assess the efficacy of omalizumab in non-allergic asthma and in combination with specific allergen immunotherapy, with the aim of reducing systemic allergic reactions [16]. The adverse effect profile of omalizumab is generally good [17] although preliminary data from a five-year safety study has raised concerns about a trend for increased cardiovascular events and further confirmation is awaited $[18,19]$.

A number of biological agents have been developed to target cytokines thought to play an important role in asthma pathogenesis $[20,21]$, including monoclonal antibody blockers of TNF- $\alpha$, IL-5, IL-4 and IL-13. Unfortunately despite some promise shown in early small clinical studies with the soluble TNF- $\alpha$ receptor blocker, etanercept, in severe asthma [22,23], larger studies with golimumab [24] and etanercept [25] have not confirmed a consistent effect. Overall, when combined with concerns over increased risk of severe infections and malignancies with treatment [24] it is unlikely that TNF- $\alpha$ 

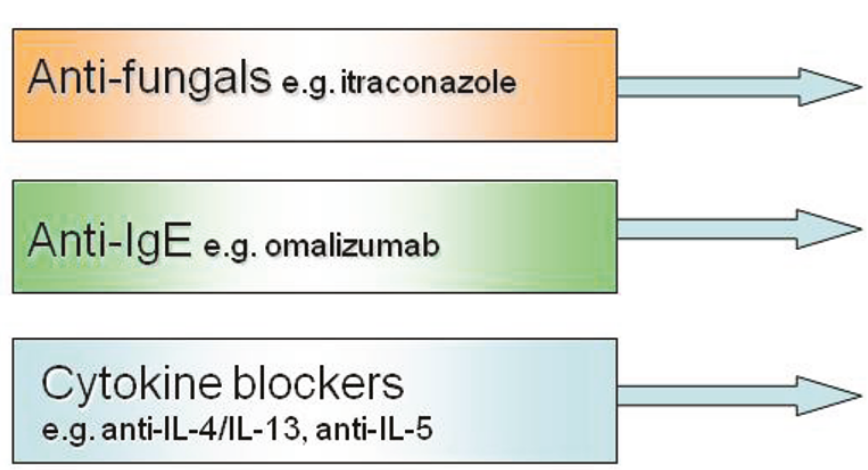

IL-4/IL-13, IL-5

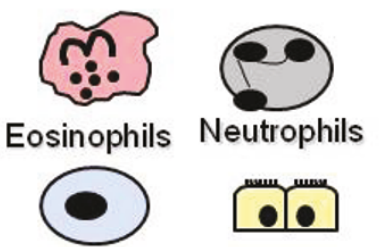

Tlymphocyte Epithelial cells

\section{Mediator antagonists} e.g. CRTH2 receptor antagonists $\left(P G D_{2}\right)$, endothelin antagonists

\section{Anti-inflammatory agents e.g. new steroids, $\mathrm{PDE}_{4}$ inhibitors, protein kinase inhibitors, statins, PPARY agonists, FLAP inhibitors}
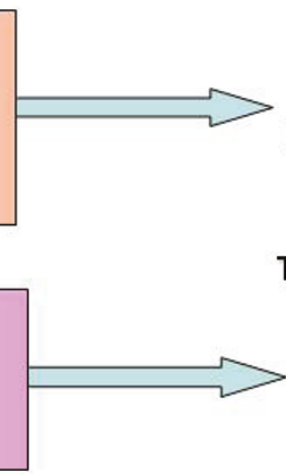

\section{Bronchodilators e.g. ultra LABAs Bronchial thermoplasty}

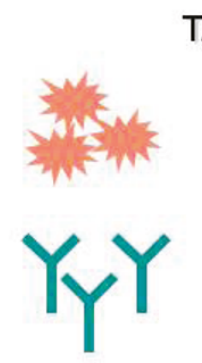

Fungi

$\lg \mathrm{E}$

\section{Inflammatory \\ cells \& pathways}

Cytokines

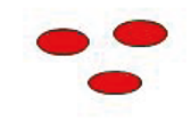

Mediators

\section{Airway smooth} muscle

Figure 1 Potential targets for selected novel therapies for treatment resistant asthma. The figure summarizes targets for a selection of therapies that are recently licensed or under clinical development for patients with severe treatment resistant asthma. Abbreviations: CRTH2, chemoattractant receptor-homologous molecule expressed on Th2 cells; FLAP, lipoxygenase-activating protein; IL-, interleukin-; PPAR, proliferatoractivated receptor; $P D E$, phosphodiesterase; $\mathrm{PGD}_{2}$, prostaglandin $\mathrm{D}_{2}$.

receptor blockers will be developed further for the treatment of asthma.

Two recent exploratory studies have examined antiIL5 monoclonal antibody (mepolizumab) treatment in patients with severe asthma [26,27]. In 61 patients with refractory eosinophilic asthma and a history of recurrent severe exacerbations mepolizumab treatment reduced severe exacerbations [27] (Figure 2) and in 20 patients with severe oral corticosteroid dependent asthma an oral corticosteroid sparing effect was observed [26]. Phase 3 trials are now underway. The relevance of this approach to clinical practice has been debated [28] as possibly only a small proportion of patients with persistent sputum eosinophilia are also concordant with inhaled or oral corticosteroid treatment [29].

A number of clinical trials employing monoclonal antibodies targeting IL-4 and/or IL-13 in asthma are underway [30,31]. Both cytokines exert their actions through the IL-4R $\alpha /$ IL-13R $\alpha 1$ receptor complex. Blocking IL-13 binding to the IL-4 receptor $\alpha$ with IMA-638 reduces allergen-induced bronchoconstriction [32]. Pitrakinra, a recombinant protein that binds to IL-4R $\alpha$, reduces allergen-induced late responses with few adverse events [33] and is undergoing development as an inhaled medication. A clearer picture of the role of IL-4 and IL-13 blockers in the treatment of severe asthma is likely to emerge over the next few years.

Daclizumab is a humanized monoclonal antibody that binds specifically to the CD25 subunit of the high-affinity IL-2R, and inhibits IL-2 binding and T-cell activation. A pilot study of daclizumab in patients with moderate to severe asthma reported minor improvements in lung function and asthma control [34]. 


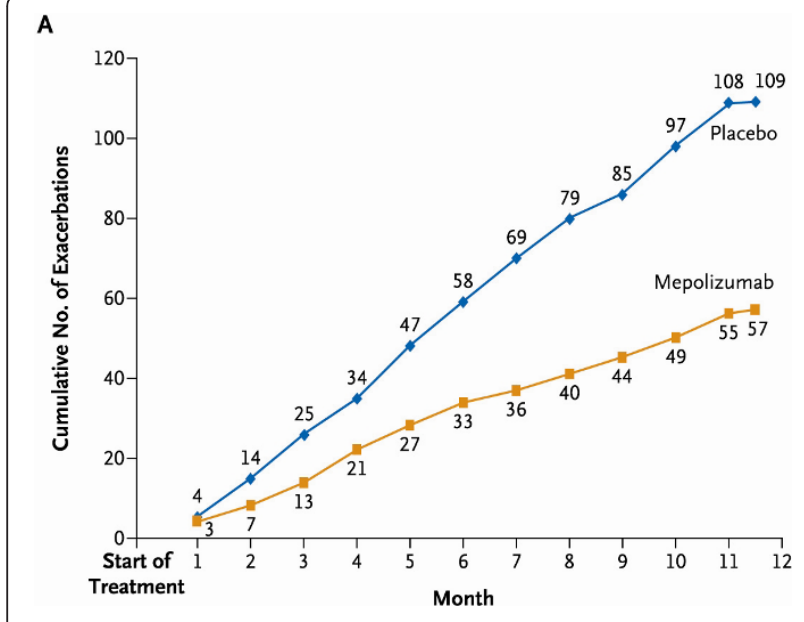

Figure 2 Cumulative number of severe exacerbations in each study group over the course of $\mathbf{5 0}$ weeks treatment with mepolizumab or placebo. Mean number of exacerbations per subject over the course of the 50-week treatment period was 2.0 in the mepolizumab group, compared with 3.4 in the placebo group (relative risk, $0.57 ; 95 \%$ confidence interval, 0.32 to $0.92 ; P=0.02$ ).

Reproduced from Haldar et al with permission [27]. Copyright (c) Massachusetts Medical Society.

Patients with asthma may be more susceptible to respiratory viruses due to impaired $\mathrm{Th}_{1}$ immunity [35] and immunological augmentation with inhaled interferon $\beta$ to aid anti-viral responses at the time of the exacerbation is currently under assessment.

\section{New inhaled long-acting bronchodilators and corticosteroids}

In addition to the development of novel therapies, refinements in the pharmacological properties of drugs currently used to treat asthma, such as long-acting $\beta_{2}$ agonists and inhaled corticosteroids is a major focus of the pharmaceutical industry. Inhaled ultra long-acting $\beta_{2}$-agonists (ultra-LABAs) such as indacaterol, currently licensed for COPD, have a longer half-life than current LABAs and are suitable for once daily administration [36,37]. Fixed combinations of ultra-LABAs with once daily inhaled corticosteroids as well as once daily inhaled corticosteroids alone are at an advanced stage of development for the treatment of asthma. Once daily administration should be more convenient for patients and may improve adherence. New inhaled long-acting antimuscarinic agents (LAMAs) agents such as aclidinium, may also have a role in the treatment of severe asthma associated with persistent airflow obstruction [38,39]. Non-steroidal selective glucocorticoid receptor modulators are in development with the aim of improving the therapeutic ratio of corticosteroids by dissociating transactivation, which is associated with the adverse effects of corticosteroids, from the beneficial effect of transrepression [40-43].

\section{Arachidonic acid pathway blockers}

Pro-inflammatory cysteinyl leukotrienes (LTs) are synthesized from arachidonic acid by 5-lipoxygenase (LO) and 5-lipoxygenase-activating protein (FLAP) in inflammatory airway cells. In addition to inhibiting the production of the cysteinyl LTs, 5-LO and FLAP inhibitors such as GSK-2190915 [44] prevent the formation of $\mathrm{LTB}_{4}$, which may be of value in neutrophilic asthma. Prostaglandin (PG) $\mathrm{D}_{2}$ is released from mast cells and other inflammatory cells and elevated bronchoalveolar lavage concentrations of $\mathrm{PGD}_{2}$ are reported in severe asthma [45]. $\mathrm{PGD}_{2}$ activates the CRTH2 receptor (chemoattractant receptor-homologous molecule expressed on $\mathrm{Th}_{2}$ cells) resulting in inflammation and a number of antagonists of the CRTH2 receptor are being assessed for the treatment of asthma [46].

\section{Bronchial thermoplasty}

Bronchial thermoplasty involves the delivery of radio frequency energy to the airways by flexible bronchoscopy with the aim of reducing airway smooth muscle mass and responsiveness in asthma [47-50]. Initial clinical studies including the Asthma Intervention Research (AIR) 1 trial found that bronchial thermoplasty reduces exacerbations and improves morning peak expiratory flow and symptoms in patients with severe asthma [51-53]. The AIR2 trial reported the results of a comparison with sham bronchial thermoplasty in 288 adult subjects with severe asthma [54]. Bronchial thermoplasty resulted in improvements from baseline in Asthma Quality of Life Questionnaire (AQLQ) scores compared with sham (bronchial thermoplasty, 1.35 versus sham, 1.16), with $79 \%$ of bronchial thermoplasty and $64 \%$ of sham subjects achieving changes in AQLQ of 0.5 or greater (Figure 3). It is of interest that the sham bronchial thermoplasty was associated with a large increase in AQLQ scores. In the post-treatment period, the bronchial thermoplasty group also experienced fewer severe exacerbations and emergency department visits. However bronchial thermoplasty was associated with a shortterm increase in asthma-related morbidity. Long-term five-year safety data for patients recruited to the AIR1 trial [52] reported absence of clinical complications and maintenance of stable lung function [55]. In 2010 bronchial thermoplasty was approved by the United States Food \& Drug Administration (FDA) for the treatment of severe persistent asthma. Future research needs to identify factors that best predict a therapeutic response to bronchial thermoplasty.

\section{Other anti-inflammatory drugs}

A number of novel drugs under development may prove to have a role in the management of asthma. Phosphodiesterase $(\mathrm{PDE})_{4}$ inhibitors have immunomodulatory 


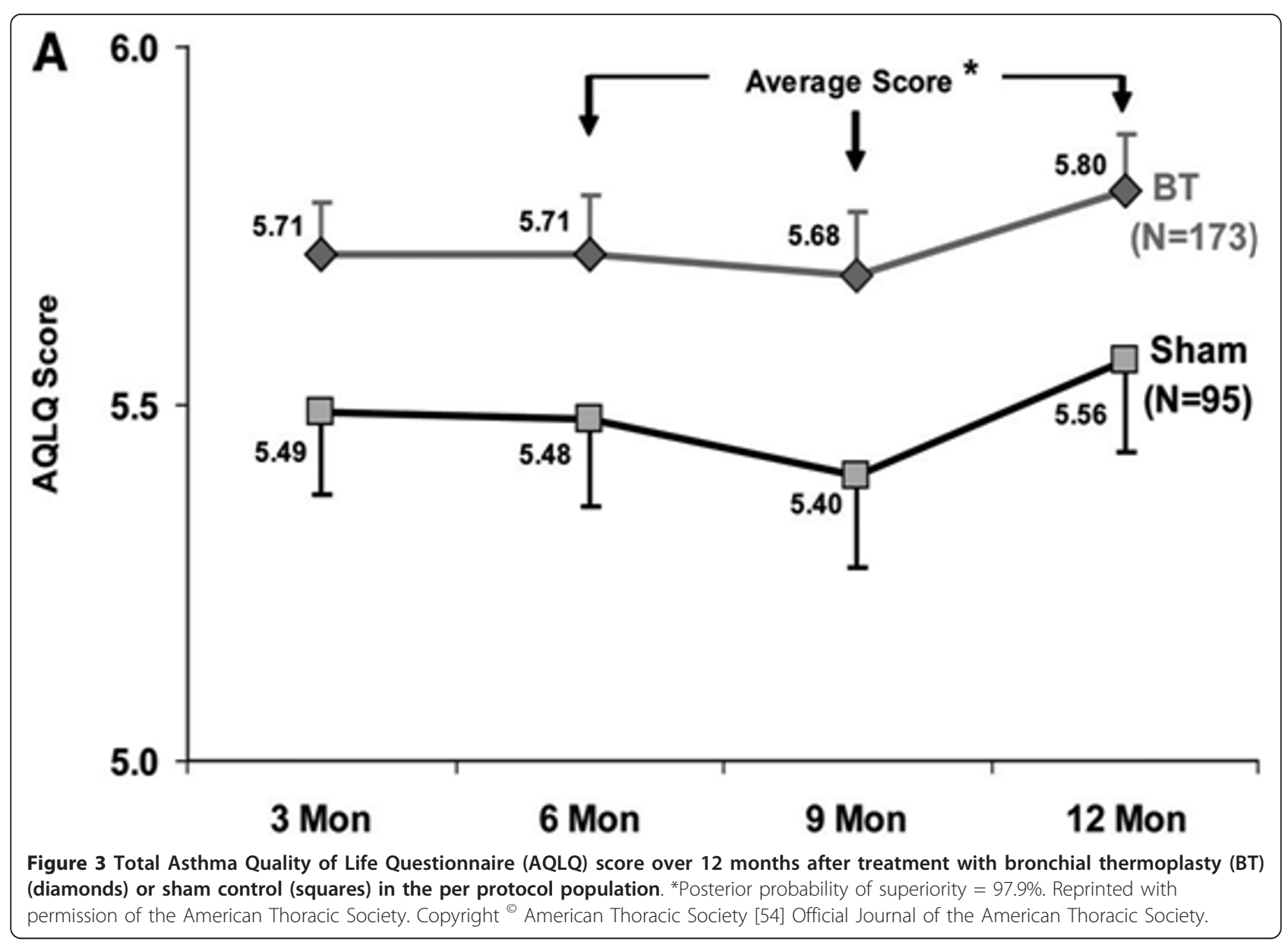

effects over a number of inflammatory cells potentially relevant to the treatment of severe asthma [56]. High doses of phosphodiesterase (PDE) $)_{4}$ inhibitors may be necessary to treat severe asthma, and gastro-intestinal side effects may limit their use [56-58], although inhaled $\mathrm{PDE}_{4}$ inhibitors may improve their therapeutic index $[59,60]$. Inhibition of protein kinases such as p38 mitogen-activated protein kinase (MAPK) and other tyrosine kinases involved in cellular signalling of pro-inflammatory cytokines may have a role in the treatment of severe asthma [61-63]. For example, a phase 3 study evaluating a tyrosine kinase inhibitor of the c-KIT receptor masitinib commenced recently.

Several drugs licensed for treating other conditions may also have a role in the management of asthma. In a randomized controlled trial of 58 patients with severe asthma with fungal sensitization (SAFS) [64] the oral anti-fungal drug itraconazole administered for 32 weeks resulted in improvement in AQLQ scores [65]. However the risk of adrenal suppression with long-term treatment with itraconazole in patients also receiving inhaled corticosteroids has led to some caution in adopting this management strategy $[66,67]$. Peroxisome proliferator- activated receptor- $\gamma$ (PPAR $\gamma$ ) agonists exert anti-inflammatory effects on eosinophilic and neutrophilic infiltration of the lungs of experimental animals [68]. A proof of concept study using the PPAR $\gamma$ agonist rosiglitazone, demonstrated bronchodilator effects in mild to moderate smokers with asthma [69] and further clinical trials of oral PPAR $\gamma$ agonists are underway in severe asthma. Statins have pleiotropic anti-inflammatory effects potentially relevant to the treatment of asthma [70-76]. Shortterm treatment of patients with mild to moderate asthma with statins does not improve symptoms or lung function [77-80], although AQLQ scores improve in asthmatic smokers [80]. The small peptide endothelin causes bronchoconstriction and may contribute to airway remodelling in asthma $[81,82]$. A 12-month clinical trial of the endothelin receptor antagonist sitaxsentan is underway in patients with severe asthma.

\section{Factors influencing the response to novel therapies}

Genotypic and phenotypic factors can influence the response to drug treatment for asthma $[23,26,27,83]$. For example, adrenergic $\beta_{2}$-receptor polymorphisms, particularly variants at position 16 (Gly16Arg) and 27 
(Gln27Glu), have been associated with impaired bronchodilator response to short and long-acting $\beta_{2}$-receptor agonists and naturally occurring mutations in the promoter of 5-lipoxygenase gene (ALOX5) may influence the clinical response to drugs modifying the 5-lipoxygenase pathway [84-86]. Several inflammatory phenotypes, which have been identified mainly on the basis of induced sputum cell profiles, influence the response to drug treatment $[87,88]$. For example, sputum eosinophilia predicts corticosteroid responsiveness [89-93] and the response to the anti-IL- 5 blocker mepolizumab in severe asthma [26,27]. Non-eosinophilic asthma, a term used to describe an absence of raised numbers of inflammatory cells (also known as paucigranulocytic inflammation) or neutrophilic inflammation, responds less well to inhaled corticosteroids [91-93]. Macrolides may be effective in neutrophilic asthma [94]. $\mathrm{Th}_{2}$-high asthma, as defined by gene expression analyses of airway cells, predicts an improvement in lung function with inhaled corticosteroids in patients with mild to moderate disease, whereas patients with $\mathrm{Th}_{2}$-low asthma respond poorly to inhaled corticosteroids [95]. The development of novel therapies for severe asthma in the future is likely to involve genotypic and/or phenotypic assessment to identify patients who will gain the most from a specific intervention.

\section{Conclusions and future directions}

Omalizumab, a humanized monoclonal antibody that binds circulating IgE antibody, and bronchial thermoplasty, where radio frequency energy is delivered to the airways to reduce airway smooth muscle mass are valuable additional therapies for the management of severe asthma. There is a need to identify new therapies that are effective and safe and target sub-phenotypes of asthma. Of therapies currently under development, biological agents directed at blocking pro-inflammatory cytokines such as interleukin-5 and interleukin-13, ultra long-acting $\beta_{2}$-agonists and once daily inhaled corticosteroids as well as drugs blocking components of the arachidonic acid pathway such as FLAP inhibitors and CRTH2 receptor antagonists have the greatest potential to reach the clinic. In the future, both genotypic and phenotypic factors are likely to guide the choice of intervention in each individual with severe asthma.

\section{List of abbreviations}

AIR trial: Asthma Intervention Research trial; AQLQ: asthma quality of life questionnaire; CRTH2: chemoattractant receptor-homologous molecule expressed on Th, cells; FDA: U.S. Food \& Drug Administration; FLAP: lipoxygenase-activating protein; IL-: interleukin; LAMAs: long-acting antimuscarinic agents; LO: lipoxygenase; LTs: leukotrienes; MAPK: mitogenactivated protein kinase; PPAR: proliferator-activated receptor; PDE: phosphodiesterase; $P G D_{2}$ : prostaglandin $D_{2}$ SAFS: severe asthma with fungal sensitization; TNF: tumor necrosis factor; Ultra-LABAs: ultra long-acting $\beta_{2-}$ agonists.

\section{Authors' contributions}

NCT conceived the article and prepared the initial draft of the manuscript. All authors drafted further versions of the manuscript and approved the final version.

\section{Competing interests}

$\mathrm{NCT}$ received industry-sponsored grant funding from Aerovance, Asthmatx, Glaxo Smithkline, Medlmmune Ltd, Novartis, Centocor and Synairgen for participating in clinical trials.

Received: 29 April 2011 Accepted: 6 September 2011

Published: 6 September 2011

\section{References}

1. GINA Report, Global Strategy for Asthma Management and Prevention. [http://www.ginasthma.com].

2. British Thoracic Society Scottish Intercollegiate Guidelines Network: Thorax 2008, 63:iv1-iv121.

3. Expert Panel Report 3 (EPR-3): Guidelines for the Diagnosis and Management of Asthma-Summary Report 2007. J Allergy Clin Immunol 2007, 120:S94-S138.

4. Partridge $M$, van der Molen T, Myrseth S-E, Busse W: Attitudes and actions of asthma patients on regular maintenance therapy: the INSPIRE study. BMC Pulm Med 2006, 6:13.

5. Dockrell M, Partridge M, Valovirta E: The limitations of severe asthma: the results of a European survey. Allergy 2007, 62:134-141

6. Spears M, Cameron E, Chaudhuri R, Thomson NC: Challenges of treating asthma in people who smoke. Expert Rev Clin Immunol 2010, 6:257-268.

7. Chaudhuri R, McSharry C, McCoard A, Livingston E, Hothersall E, Spears M, Lafferty J, Thomson NC: Role of symptoms and lung function in determining asthma control in smokers with asthma. Allergy 2008 , 63:132-135.

8. Heaney LG, Brightling CE, Menzies-Gow A, Stevenson M, Niven RM, British Thoracic Society Difficult Asthma Network: Refractory asthma in the UK: cross-sectional findings from a UK multicentre registry. Thorax 2010, 65:787-794.

9. Bel E, Sousa A, Fleming L, Bush A, Chung K, Versnel J, Wagener A, Wagers S, Sterk P, Compton C, the Unbiased Biomarkers for the Prediction of Respiratory Disease Outcome (U-BIOPRED) Consortium, Consensus Generation: Diagnosis and definition of severe refractory asthma: an international consensus statement from the Innovative Medicine Initiative (IMI). Thorax 2011, 153643 Published Online First: 23 November 2010.

10. Holgate ST, Polosa R: The mechanisms, diagnosis, and management of severe asthma in adults. The Lancet 2006, 368:780-793.

11. Adcock IM, Caramori G, Chung KF: New targets for drug development in asthma. Lancet 2008, 372:1073-1087.

12. Barnes PJ: New therapies for asthma: is there any progress? Trends Pharmacolog Sci 2010, 31:335-343

13. Hamelmann E: The rationale for treating allergic asthma with anti-lgE. Eur Respir Rev 2007, 16:61-66.

14. Walker S, Monteil M, Phelan K, Lasserson T, Walters E: Anti-lgE for chronic asthma in adults and children. Cochrane Database of Systematic Reviews 2006.

15. Rodrigo GJ, Neffen H, Castro-Rodriguez JA: Efficacy and Safety of Subcutaneous Omalizumab vs Placebo as Add-on Therapy to Corticosteroids for Children and Adults With Asthma. Chest 2011, 139:28-35

16. Casale TB, Stokes JR: Future forms of immunotherapy. J Allergy Clin Immunol 2011, 127:8-15.

17. Corren J, Casale TB, Lanier B, Buhl R, Holgate S, Jimenez P: Safety and tolerability of omalizumab. Clin Exp Allergy 2009, 39:788-797.

18. Aidan AL, James EF, Abdelkader R, Mary KM, Mary SB, Hassan NT, Anthony ND, Stephen AT, Stanley JS: Baseline characteristics of patients enrolled in EXCELS: a cohort study. Ann Allergy Asthma Immunol 2009, 103:212-219.

19. Omalizumab: potential risk of arterial thrombotic events. Drug Safety Update 2011, 4:A4. 
20. Holgate ST, Arshad HS, Roberts GC, Howarth PH, Thurner P, Davies DE: A new look at the pathogenesis of asthma. Clin Sci 2010, 118:439-450

21. Levine $S$, Wenzel S: Narrative review: the role of Th2 immune pathway modulation in the treatment of severe asthma and its phenotypes. Ann Intern Med 2010, 152:232-237.

22. Howarth PH, Babu KS, Arshad HS, Lau L, Buckley M, McConnell W, Beckett P, Al Ali M, Chauhan A, Wilson SJ, Reynolds A, Davies DE, Holgate ST: Tumour necrosis factor (TNF\{alpha\}) as a novel therapeutic target in symptomatic corticosteroid dependent asthma. Thorax 2005, 60:1012-1018

23. Berry M, Hargadon B, Shelley M, Parker D, Shaw D, Green R, Bradding P, Brightling C, Wardlaw A, Pavord I: Inhibition of Tumor Necrosis Factor a for Refractory Asthma. N Eng J Med 2006, 354:754-758.

24. Wenzel SE, Barnes PJ, Bleecker ER, Bousquet J, Busse W, Dahlen S-E, Holgate ST, Meyers DA, Rabe KF, Antczak A, Baker J, Horvath I, Mark Z, Bernstein D, Kerwin E, Schlenker-Herceg R, Lo KH, Watt R, Barnathan ES, Chanez P, T03 Asthma Investigators: A Randomized, Double-blind, Placebo-controlled Study of Tumor Necrosis Factor-\{alpha\} Blockade in Severe Persistent Asthma. Am J Respir Crit Care Med 2009, 179:549-558.

25. Holgate ST, Noonan M, Chanez P, Busse W, Dupont L, Pavord I, Hakulinen A, Paolozzi L, Wajdula J, Zang C, Nelson H, Raible D: Efficacy and safety of etanercept in moderate-to-severe asthma: a randomised, controlled trial. Eur Respir J 2011, 37:1352-1359.

26. Nair P, Pizzichini MMM, Kjarsgaard M, Inman MD, Efthimiadis A, Pizzichini $E$, Hargreave FE, O'Byrne PM: Mepolizumab for Prednisone-Dependent Asthma with Sputum Eosinophilia. N Engl J Med 2009, 360:985-993.

27. Haldar P, Brightling CE, Hargadon B, Gupta S, Monteiro W, Sousa A Marshall RP, Bradding P, Green RH, Wardlaw AJ, Pavord ID: Mepolizumab and Exacerbations of Refractory Eosinophilic Asthma. N Engl J Med 2009, 360:973-984.

28. Wenzel SE: Eosinophils in Asthma-Closing the Loop or Opening the Door? N Engl J Med 2009, 360:1026-1028.

29. Gamble J, Stevenson M, McClean E, Heaney LG: The Prevalence of Nonadherence in Difficult Asthma. Am J Respir Crit Care Med 2009, 180:817-822

30. Corren J: Cytokine inhibition in severe asthma: Current knowledge and future directions. Curr Opin Pulm Med 2011, 17:29-33.

31. Elias JA, Lee CG: IL-13 in Asthma: The Successful Integration of Lessons from Mice and Humans. Am J Respir Crit Care Med 2011, 183:957-958.

32. Gauvreau GM, Boulet L-P, Cockcroft DW, FitzGerald JM, Carlsten C, Davis BE, Deschesnes F, Duong M, Durn BL, Howie KJ, Hui L, Kasaian MT, Killian K, Strinich TX, Watson RM, Y N, Zhou S, Raible D, O'Byrne PM: The Effects of IL-13 Blockade on Allergen-Induced Airway Responses in Mild Atopic Asthma. Am J Respir Crit Care Med 2011, 183:1007-1014.

33. Wenzel S, Wilbraham D, Fuller R, Getz EB, Longphre M: Effect of an interleukin-4 variant on late phase asthmatic response to allergen challenge in asthmatic patients: results of two phase $2 \mathrm{a}$ studies. The Lancet 2007, 370:1422-1431

34. Busse WW, Israel E, Nelson HS, Baker JW, Charous BL, Young DY, Vexler V, Shames RS, the Daclizumab Asthma Study Goup: Daclizumab Improves Asthma Control in Patients with Moderate to Severe Persistent Asthma: A Randomized, Controlled Trial. Am J Respir Crit Care Med 2008, 178:1002-1008

35. Message SD, Laza-Stanca $\mathrm{V}_{\text {, Mallia }} \mathrm{P}$, Parker HL, Zhu J, Kebadze T, Contoli M Sanderson G, Kon OM, Papi A, Jeffery PK, Stanciu LA, Johnston SL: Rhinovirus induced lower respiratory illness is increased in asthma and related to virus load and Th1/2 cytokine and IL-10 production. Proc Nat Acad Sci USA 2008, 105:13562-13567.

36. Cazzola M, Segreti A, Matera M: Novel bronchodilators in asthma. Curr Opin Pulm Med 2010, 16:6-12

37. Cazzola M, Matera MG: Novel long-acting bronchodilators for COPD and asthma. Br J Pharmacol 2008, 155:291-299.

38. Thomson NC, Spears M: The role of cigarette smoking on persistent airflow obstruction in asthma. Annals Resp Med 2011.

39. Park HW, Yang MS, Park CS, Kim TB, Moon HB, Min KU, Kim YY, Cho SH: Additive role of tiotropium in severe asthmatics and Arg16Gly in ADRB2 as a potential marker to predict response. Allergy 2009, 64:778-783.

40. De Bosscher $K$, Haegeman G, Elewaut D: Targeting inflammation using selective glucocorticoid receptor modulators. Curr Opin Pharmacol 2010, 10:497-504.
41. Schacke H, Schottelius A, Docke W-D, Strehlke P, Jaroch S, Schmees N Rehwinkel $\mathrm{H}$, Hennekes $\mathrm{H}$, Asadullah $\mathrm{K}$ : Dissociation of transactivation from transrepression by a selective glucocorticoid receptor agonist leads to separation of therapeutic effects from side effects. Proc Natl Acad Sci USA 2004, 101:227-232.

42. Schäcke H, Zollner TM, Döcke WD, Rehwinkel H, Jaroch S, Skuballa W, Neuhaus R, May E, Zügel U, Asadullah K: Characterization of ZK 245186, a novel, selective glucocorticoid receptor agonist for the topical treatment of inflammatory skin diseases. Br J Pharmacol 2009, 158:1088-1103.

43. Zhang J, Cavet M, VanderMeid K, Salvador-Silva M, López F, Ward K: BOL303242-X, a novel selective glucocorticoid receptor agonist, with full anti-inflammatory properties in human ocular cells. Mol Vis 2009, 15:2606-2616.

44. Evans JF, Ferguson AD, Mosley RT, Hutchinson JH: What's all the FLAP about?: 5-lipoxygenase-activating protein inhibitors for inflammatory diseases. Trends Pharmacol Sc 2008, 29:72-78.

45. Balzar S, Fajt ML, Comhair SAA, Erzurum SC, Bleecker E, Busse WW, Castro M, Gaston B, Israel E, Schwartz LB, Curran-Everett D, Moore CG, Wenzel SE: Mast Cell Phenotype, Location, and Activation in Severe Asthma: Data from the Severe Asthma Research Program. Am J Respir Crit Care Med 2011, 183:299-309.

46. Schuligoi R, Sturm E, Luschnig P, Konya V, Philipose S, Sedej M, Waldhoer M, Peskar BA, Heinemann A: CRTH2 and D-Type Prostanoid Receptor Antagonists as Novel Therapeutic Agents for Inflammatory Diseases. Pharmacology 2010, 85:372-382.

47. Cox PG, Miller J, Mitzner W, Leff AR: Radiofrequency ablation of airway smooth muscle for sustained treatment of asthma: preliminary investigations. Eur Respir J 2004, 24:659-663.

48. Danek CJ, Lombard CM, Dungworth DL, Cox PG, Miller JD, Biggs MJ, Keast TM, Loomas BE, Wizeman WJ, Hogg JC, Leff AR: Reduction in airway hyperresponsiveness to methacholine by the application of RF energy in dogs. J Appl Physiol 2004, 97:1946-1953.

49. Brown RH, Wizeman W, Danek C, Mitzner W: In vivo evaluation of the effectiveness of bronchial thermoplasty with computed tomography. J Appl Physiol 2005, 98:1603-1606.

50. Brown RH, Wizeman W, Danek C, Mitzner W: Effect of bronchial thermoplasty on airway distensibility. Eur Respir J 2005, 26:277-282

51. Cox G, Miller JD, McWilliams A, FitzGerald JM, Lam S: Bronchia Thermoplasty for Asthma. Am J Respir Crit Care Med 2006, 173:965-969.

52. Cox G, Thomson NC, Rubin AS, Niven RM, Corris PA, Siersted HC, Olivenstein R, Pavord ID, McCormack D, Chaudhuri R, Miller JD, Laviolette M, AIR Trial Study Group: Asthma Control during the Year after Bronchial Thermoplasty. N Eng J Med 2007, 356:1327-1337.

53. Pavord ID, Cox G, Thomson NC, Rubin AS, Corris PA, Niven RM, Chung KF, Laviolette M, the RISA Trial Study Group: Safety and Efficacy of Bronchial Thermoplasty in Symptomatic, Severe Asthma. Am J Respir Crit Care Med 2007, 176:1185-1191

54. Castro M, Rubin AS, Laviolette M, Fiterman J, De Andrade Lima M, Shah PL, Fiss E, Olivenstein R, Thomson NC, Niven RM, Pavord ID, Simoff $M$ Duhamel DR, McEvoy C, Barbers R, Ten Hacken NH, Wechsler ME, Holmes M, Phillips MJ, Erzurum S, Lunn W, Israel E, Jarjour N, Kraft M, Shargill NS, Quiring J, Berry SM, Cox G, AIR2 Trial Study Group: Effectiveness and Safety of Bronchial Thermoplasty in the Treatment of Severe Asthma: A Multicenter, Randomized, Double-Blind, ShamControlled Clinical Trial. Am J Respir Crit Care Med 2010, 181:116-124.

55. Thomson N, Rubin A, Niven R, Corris P, Siersted H, Olivenstein R, Pavord I, McCormick D, Laviolette M, Shargill N, Cox G, AIR Trial Study Group: Long term (5 Year) safety of bronchial thermoplasty: Asthma Intervention Research (AIR) trial. BMC Pulm Med 2011, 11:8.

56. Lipworth BJ: Phosphodiesterase-4 inhibitors for asthma and chronic obstructive pulmonary disease. The Lancet 2005, 365:167-175.

57. Bateman ED, Izquierdo JL, Harnest U, Hofbauer P, Magyar P, SchmidWirlitsch C, Leichtl S, Bredenbroker D: Efficacy and safety of roflumilast in the treatment of asthma. Ann Allergy Asthma \& Immunol 2006, 96:679-686.

58. Bousquet J, Aubier M, Sastre J, Izquierdo JL, Adler LM, Hofbauer P, Rost KD, Harnest U, Kroemer B, Albrecht A, Bredenbröker D: Comparison of roflumilast, an oral anti-inflammatory, with beclomethasone dipropionate in the treatment of persistent asthma. Allergy 2006, 61:72-78.

59. Chapman RW, House A, Richard J, Prelusky D, Lamca J, Wang P, Lundell D, Wu P, Ting PC, Lee JF, Aslanian R, Phillips JE: Pharmacology of a potent 
and selective inhibitor of PDE4 for inhaled administration. Eur Pharmacol 2010, 643:274-281.

60. Singh D, Petavy F, Macdonald A, Lazaar A, O'Connor B: The inhaled phosphodiesterase 4 inhibitor GSK256066 reduces allergen challenge responses in asthma. Resp Res 2010, 11:26.

61. Cohen S, Fleischmann R: Kinase inhibitors: a new approach to rheumatoid arthritis treatment. Curr Opin Rheumatol 2010, 22:330-335.

62. Hammaker D, Firestein G: "Go upstream, young man": lessons learned from the p38 saga. Ann Rheum Dis 2010, 69(Suppl 1):i77-82.

63. Bhavsar P, Khorasani N, Hew M, Johnson M, Chung KF: Effect of p38 MAPK inhibition on corticosteroid suppression of cytokine release in severe asthma. Eur Respir J 2010, 35:750-756.

64. Denning DW, O'Driscoll BR, Hogaboam CM, Bowyer P, Niven RM: The link between fungi and severe asthma: a summary of the evidence. Eur Respir J 2006, 27:615-626

65. Denning DW, O'Driscoll BR, Powell G, Chew F, Atherton GT, Vyas A, Miles J, Morris J, Niven RM: Randomized Controlled Trial of Oral Antifungal Treatment for Severe Asthma with Fungal Sensitization: The Fungal Asthma Sensitization Trial (FAST) Study. Am J Respir Crit Care Med 2009, 179:11-18.

66. Parma J, Howell T, Kelly J, Bilton D: Profound adrenal suppression secondary to treatment with low dose inhaled steroids and itraconazole in allergic bronchopulmonary aspergillosis in cystic fibrosis. Thorax 2002, 57:749-750.

67. Skov M, Main K, Sillesen I, Müller J, Koch C, Lanng S: latrogenic adrenal insufficiency as a side-effect of combined treatment of itraconazole and budesonide. Eur Respir J 2002, 20:127-133.

68. Spears M, McSharry C, Thomson NC: Peroxisome proliferator-activated receptor-gamma agonists as potential anti-inflammatory agents in asthma and chronic obstructive pulmonary disease. Clin Exp Allergy 2006, 36:1494-1504.

69. Spears M, Donnelly I, Jolly L, Brannigan M, Ito K, McSharry C, Lafferty J, Chaudhuri R, Braganza G, Bareille P, Sweeney L, Adcock IM, Barnes PJ, Wood S, Thomson NC: Bronchodilatory Effect of the PPAR-[gamma] Agonist Rosiglitazone in Smokers With Asthma. Clin Pharmacol Ther 2009, 86:49-53.

70. Hothersall E, McSharry C, Thomson NC: Potential therapeutic role for statins in respiratory disease. Thorax 2006, 61:729-734.

71. Kim DY, Ryu SY, Lim JE, Lee YS, Ro JY: Anti-inflammatory mechanism of simvastatin in mouse allergic asthma model. Eur J Pharmacol 2007, 557:76-86.

72. Chiba Y, Sato S, Misawa M: Inhibition of antigen-induced bronchial smooth muscle hyperresponsiveness by lovastatin in mice. J Smooth Muscle Res 2008, 44:123-128.

73. Imamura M, Okunishi K, Ohtsu H, Nakagome K, Harada $H$, Tanaka R, Yamamoto K, Dohi M: Pravastatin attenuates allergic airway inflammation by suppressing antigen sensitisation, interleukin 17 production and antigen presentation in the lung. Thorax 2009, 64:44-49.

74. Chiba Y, Arima J, Sakai H, Misawa M: Lovastatin inhibits bronchial hyperresponsiveness by reducing RhoA signaling in rat allergic asthma. Am J Physiol Lung Cell Mol Physiol 2008, 294:L705-713.

75. McKay A, Leung BP, McInnes IB, Thomson NC, Liew FY: A Novel AntiInflammatory Role of Simvastatin in a Murine Model of Allergic Asthma. J Immunol 2004, 172:2903-2908.

76. Zeki AA, Franzi L, Last J, Kenyon NJ: Simvastatin Inhibits Airway Hyperreactivity: Implications for the Mevalonate Pathway and Beyond. Am J Respir Crit Care Med 2009, 180:731-740.

77. Menzies D, Nair A, Meldrum KT, Fleming D, Barnes M, Lipworth BJ: Simvastatin does not exhibit therapeutic anti-inflammatory effects in asthma. J Allergy Clin Immunol 2007, 119:328-335.

78. Hothersall EJ, Chaudhuri R, McSharry C, Donnelly I, Lafferty J, McMahon AD, Weir CJ, Meiklejohn J, Sattar N, Mclnnes I, Wood S, Thomson NC: Effects of atorvastatin added to inhaled corticosteroids on lung function and sputum cell counts in atopic asthma. Thorax 2008, 63:1070-1075.

79. Cowan DC, Cowan JO, Palmay R, Williamson A, Taylor DR: Simvastatin in the treatment of asthma: lack of steroid-sparing effect. Thorax 2010, 65:891-896.

80. Braganza G, Chaudhuri R, McSharry C, Weir CJ, Donnelly I, Jolly L, Lafferty J, Lloyd SM, Spears M, Mair F, Thomson NC: Effects of short-term treatment with atorvastatin in smokers with asthma-a randomized controlled trial. BMC Pulm Med 2011, 11:16
81. Pégorier S, Arouche N, Dombret M-C, Aubier M, Pretolani M: Augmented epithelial endothelin-1 expression in refractory asthma. J Allergy Clin Immunol 2007, 120:1301-1307.

82. McWhinnie R, Pechkovsky DV, Zhou D, Lane D, Halayko AJ, Knight DA, Bai TR: Endothelin-1 induces hypertrophy and inhibits apoptosis in human airway smooth muscle cells. Am J Physiol Lung Cell Mol Physiol 2007, 292:L278-L286.

83. Wenzel SE: Asthma: defining of the persistent adult phenotypes. The Lancet 2006, 368:804-813.

84. Drazen JM, Yandava CN, Dube L, Szczerback N, Hippensteel R, Pillari A Israel E, Schork N, Silverman ES, Katz DA, Drajesk J: Pharmacogenetic association between ALOX5 promoter genotype and the response to anti-asthma treatment. Nat Genet 1999, 22:168-170.

85. Lima JJ, Zhang S, Grant A, Shao L, Tantisira KG, Allayee H, Wang J, Sylvester J, Holbrook J, Wise R, Weiss ST, Barnes K: Influence of Leukotriene Pathway Polymorphisms on Response to Montelukast in Asthma. Am J Repir Crit Care Med 2006, 173:379-385.

86. Klotsman M, York T, Pillai S, Vargas-Irwin C, Sharma S, van den Oord E, Anderson W: Pharmacogenetics of the 5-lipoxygenase biosynthetic pathway and variable clinical response to montelukast. Pharmacogenet Genomics 2007, 17:189-196.

87. Haldar P, Pavord ID: Noneosinophilic asthma: A distinct clinical and pathologic phenotype. J Allergy Clin Immunol 2007, 119:1043-1052.

88. Simpson J, Scott R, Boyle M, Gibson P: Inflammatory subtypes in asthma: Assessment and identification using induced sputum. Respirology 2006, 11:54-61.

89. Pavord I, Brightling C, Woltmann G, Wardlaw A: Non-eosinophilic corticosteroid unresponsive asthma. Lancet 1999, 353:2213-2214

90. Little S, Chalmers G, MacLeod K, McSharry C, Thomson N: Non-invasive markers of airway inflammation as predictors of oral steroid responsiveness in asthma. Thorax 2000, 53:232-234.

91. Green $\mathrm{RH}$, Brightling $\mathrm{CE}$, McKenna S, Hargadon B, Parker D, Bradding P, Wardlaw AJ, Pavord ID: Asthma exacerbations and sputum eosinophil counts: a randomised controlled trial. The Lancet 2002, 360:1715-1721.

92. Bacci E, Cianchetti S, Bartoli M, Dente FL, Di Franco A, Vagaggini B, Paggiaro P: Low Sputum Eosinophils Predict the Lack of Response to Beclomethasone in Symptomatic Asthmatic Patients. Chest 2006, 129:565-572.

93. Berry M, Morgan A, Shaw DE, Parker D, Green R, Brightling C, Bradding P, Wardlaw AJ, Pavord ID: Pathological features and inhaled corticosteroid response of eosinophilic and non-eosinophilic asthma. Thorax 2007 62:1043-1049.

94. Simpson JL, Powell H, Boyle MJ, Scott RJ, Gibson PG: Clarithromycin Targets Neutrophilic Airway Inflammation in Refractory Asthma. Am J Respir Crit Care Med 2008, 177:148-155.

95. Woodruff PG, Modrek B, Choy DF, Jia G, Abbas AR, Ellwanger A, Arron JR, Koth LL, Fahy JV: T-helper Type 2-driven Inflammation Defines Major Subphenotypes of Asthma. Am J Respir Crit Care Med 2009, 180:388-395.

\section{Pre-publication history}

The pre-publication history for this paper can be accessed here: http://www.biomedcentral.com/1741-7015/9/102/prepub

doi:10.1186/1741-7015-9-102

Cite this article as: Thomson et al: Emerging therapies for severe asthma. BMC Medicine 2011 9:102 